\title{
DEPARTMENT OF SCIENTIFIC AND INDUSTRIAL RESEARCH
}

\author{
RETURNS FOR 1959
}

\begin{abstract}
$\mathrm{T}$ THE report of the Council for Scientific and Industrial Research for the year 1959, the general theme of which is discussed elsewhere in this issue (p. 89), records gross expenditure of $£ 10,059,376$, compared with $£ 9,453,652$ in 1958 , and reduced to $£ 8,894,820$ by various receipts from industry and other sources for services rendered, of which $£ 405,514$ was from other Government departments and $£ 625,708$ from industry, $£ 483,468$ in all being recoived by the National Physical Laboratory: the net increase on 1958 was only $£ 536,907$. Grants to students amounted to $£ 659,818$, the number of research students in training being 2,144 , of whom 928 (including eighteen NATO awards) wero now ; advanced course studentships numbered 271 , and of these 251 were new, as were 39 of the 49 research fellowships, including 22 NATO awards.

Of the research students, 254 were in biology and biochemistry, 152 in chemical engineering and metallurgy, 753 in chemistry, 62 in electrical and 138 in other engineering, 134 in goology, 30 in the human sciences, 190 in mathematics and 431 in physics. The advanced course studentships were fairly evenly distributed by subject, with 45 in physics, 44 in engineering, 37 in mathematics and 35 each in geology and in chemical engineering and motallurgy; physics (14), biology and biochomistry (13) and chemistry (I1) claimed most of the research fellowships.

Grants for special researches totalled 390 , of which 247 were new, amounting to $£ 3,542,861$ in the year endod March 31, 1959, and of these 63 were in biology, 77 in chemistry, 28 in geology and geophysics, 4 in mathematics, 16 in astronomy, 35 in low-temperature work and investigations on the solid state, 20 in physics, 69 (totalling $£ 1,723,288$ ) in nucloar physics, 59 in technology and 19 in the human sciences. Of the individual grants, much the largest is that of $£ 400,000$ to the late Prof. H. W. B. Skinner for throe years from August 1, 1959, for research at the University of Liverpool in low-energy physics ; othor grants included $£ 76,060$ to Prof. A. B. Pippard for 3-5 years from May 1, 1960, for a magnetic laboratory in the University of Cambridge for the study of metals ; $£ 97,000$ to Prof. C. C. Butler, at the Imperial College of Science and Technology, London, for 2
\end{abstract}

years from October 1, 1959, for equipment for the analysis of bubble-chamber films; $£ 75,000$ to Prof. R. Hanbury-Brown at the University of Manchester for 21 years from January 1, 1960, for a new type of photoelectric stellar interferometer, and $£ 60,820$ over 3 years from April 1, 1960, to Prof. A. C. B. Lovell for research with the 250 -ft. steerable radio telescope and another $£ 52,000$ over 4 years for its maintenance.

With the exception of fire research, expenditure on which decreased to $£ 29,743$ from $£ 37,174$ in 1958 , hydraulies research $(£ 90,768 ; £ 100,650$ in 1958), watcr pollution research ( $£ 100,586$ from $£ 103,882)$ and, surprisingly, road research, which decreased by $£ 25,751$ to $£ 535,062$ (compared with $£ 441,762$ in 1957) although work on traffic safoty problems has notably expanded, the net expenditure on all branches of tho Department's work increased in 1959, though that on food investigation ( $£ 326,908)$, forest products (£139,965), Geological Survey and Museum $(£ 338,404)$ and post infestation $(£ 95,642)$ was practically unchanged. The biggest increases were in headquarters administration, etc. $(£ 436,190$ from $£ 377,905)$; National Physical Laboratory (£801,550 from $£ 737,950)$; National Engineoring Research Laboratory, $£ 606,055$ compared with $£ 507,104$ in mechanical engineering research in 1958. Expenditure on radio research was $£ 193,681$ comparod with $£ 159,398$ in 1958, and, on the new Warren Spring Laboratory, which appears for the first time in the summary of expenditure, $£ 397,413$.

Annual grants to research associations amounted to $£ 1,683,195(£ 1,700,330$ in 1958$)$ and special grants to $£ 88,570$; contributions to European nuclear research remained at $£ 1,100,000$ and expenditure on headquarters overseas liaison increased from $£ 85,583$ to $£ 92,137$.

The report records an increase in staff of the Department to 5,506; but although net recruitment over the year was satisfactory, difficulties in recruiting certain categories of staff continued. The number of research associations has now reached fifty, and at the request of the Board of Trade and the Federation of British Industries, the service of technical digests has been restarted. The Overseas Liaison Division was merged with the Headquarters Information Division at the end of the year.

\section{THE ROYAL COLLEGE OF SURGEONS OF ENGLAND}

\section{NEW LABORATORY BUILDING}

$\mathrm{I}^{\mathrm{N}}$ $\mathrm{N}$ order to understand the importance to the Royal College of Surgeons of the laboratory block which was formally opened at the ond of Mareh, brief reference must be made to the programme of rebuilding which was started in 1952 and may bo completed in 1962.

Rebuilding starticd in the south-eastern portion of the site, where the greater part of the Hunterian Museum formerly stood, and tho first phaso consisted of the Great Hall, with thrce floors of museums above it. The second phase is the Nuffield College of Surgical Sciences, a residence for eighty postgraduate students, which faces Lincoln's Inn Fields immodiately to the east of the old College buildings and to the north of the new phaso I block.

The buildings recently opened lio behind the old College and are the westward continuation of phase I, the floor-lovols corresponding exactly except that thero is a fifth story in the now block, which aceommodates the animal house. In general terms, it may be 
said that phase I is primarily a museum block, whereas the new building (phase III $a$ ) contains research laboratories and lecture and demonstration rooms.

The fourth floor is occupied by the Department of Anatomy, with a fine Dissecting Room at the western end and a Prosector's Room leading from it, in which anatomical teaching material is prepared. Running east from the Dissecting Room there is a corridor flanked by staff offices and research rooms where work is being done on the anatomy of conjoined twins, the nerve endings in the larynx, and in preparing material for electron microscopy. Research in this field is concerned with the structure of the nuclear cytoplasmic interface in normal and neoplastic cells; the electron microscopy of human gastric mucous membrane in relation to exfoliative cytology; and the electron microscopic changes produced in the prostatic epithelium of mice by hormonal stimulation.

At the western end of each story there is a large room, the size of the Dissecting Room, that on the third floor being used by the Departments of Physiology and Pharmacology as a demonstration room, with benches for experimental work. The research rooms on this floor belong to the Department of Ophthalmology, in which work is being done on the clinical applications of antibiotics in ophthalmology, with special reference at the moment to the possible exploitation of interferon in virus diseases of the eye on the distribution and nature of refractive errors, especially on the optical components during growth and on blindness, including both statistical and experimental studies. It has been established that the general pattern of retinal metabolism conforms to that of the brain, and work is being planned to seek for possible biochemical defects in the retina of rats and mice affected with hereditary degeneration of the retina.

It has been shown that sodium iodate, sodium fluoride, and a group of phenoxyalkanes can produce degeneration of the retina in the rabbit. Cysteine has been found to be effective in preventing the experimental degeneration induced by iodate and by iodoacetate, but is apparently ineffective against the phenoxyalkanes and fluoride. Work is proceeding to seek for other protective substances against both the experimentally induced lesion and spontaneously occurring blindness.
On the second floor of phase $I$ is the main Museum of Pathology and some research rooms for the professor and his lecturers. This Department has now been able to extend into the new building, having a demonstration room at the west end and more laboratories in which at present work is being done on tissue culture and $\mathrm{X}$-ray microscopy. The tissue culture work is designed to study the distribution of adenoviruses in the tonsils of normal persons in relation to age, and the incidence of virus infections of the lung. Organ culture is being carried out to assist the research already going on in the Department into lung cancer.

X-ray microscopy is being used to explore the possibilities of the method for elucidating the structure and constitution of cells and connective tissue, and to confirm by physical means some of the results obtained by histochemical techniques.

The first floor houses the Department of Dental Science, having the Odontological Museum at its western end. The research work of the Department is directed towards exploring the rtiology of pyorrhœea and dental caries. A morphological peculiarity of the interdental septum has been demonstrated whereby a trivial aberration of tooth eruption is liable to initiate a chronic ulcer between the teeth which progresses in some cases to the establishment of a pyorrhœa pocket.

On the biochemical side, research is proceeding into the amino-acid composition of enamel protein, and it has been shown that this protein is quite different from other skin keratins; and on the bacteriological side, a special study is being made of the organisms capable of living on enamel proteins.

A third problem engaging the attention of the Department is the determination of the earliest reaction of bone to metastatic deposits of carcinoma; and a study is also being made of salivary gland metabolism using radioactive tracers.

On the ground floor there are two committee rooms, a Fellows' Common Room, and an excellent lecture theatre to seat 140 students, a great asset to the College, which is, however, still short of lecture and demonstration room-space to meet all the requirements of its educational programme. The building of phase III $b$, which will complete the restoration of the College, is planned to make good these deficiencies.

\section{THE ROYAL BOTANIC GARDENS, KEW}

$\mathrm{T}$ HE Students Day at the Royal Botanic Gardens, Kew, was held this year on May 7. Many universities, schools and training colleges were represented as well as members of a number of scientific societies. Altogether, about six hundred visitors were present. The exhibits this year were not restricted to the Herbarium but were spread over the various buildings and greenhouses at the north end of the Gardens.

Many of the Herbarium exhibits were concerned with the work of the taxonomist. Starting with the collection of plants in the field, there were demonstrations of drying and mounting leading to the ultimate naming and classification of the specimens. The work of the monographer was also demonstrated, with particular reference to the genus Ficus (figs), which includes nine hundred species.
A challenge to visitors was provided by an exhibit illustrating the classification of grasses. Two contrasting sets of specimens were displayed. In one, seven of the larger tribes were illustrated by herbarium specimens which were typical in respect of their inflorescences and spikelets. Contrasted with these were a number of non-typical examples from the same tribes, in which there were certain mutual resemblances. The compact spike-like inflorescence illustrated by Chaetostichum minimum in the Chloridese, Rhytachne rottboelloides in the Andropogonese and Prionathum pholiuroides in the Danthonea were surprisingly similar. This apparent parallelism, however, was shown to be misleading, since diagnostic characters other than those of gross morphology are essential to the correct placing of a given species. The employment of other criteria such as the nature of 